\title{
MIR146A wt Allele
}

National Cancer Institute

\section{Source}

National Cancer Institute. MIR146A wt Allele. NCI Thesaurus. Code C82098.

Human MIR146 wild-type allele is located in the vicinity of $5 q 33.3$ and is 98 bases in length. This allele, which encodes MIR146 pre-miRNA, plays a role in the regulation of gene expression. Alteration in the expression of this gene is associated with the development of cancers of the liver, breast, thyroid, ovary and prostate as well as Alzheimer's disease. 